\title{
Current status of Calotes liocephalus Günther, 1872 (Reptilia: Agamidae) of Sri Lanka
}

\author{
A.A. Thasun Amarasinghe ${ }^{1}$, D.M.S. Suranjan Karunarathna ${ }^{2} \&$ Dinesh E. Gabadage $^{3}$ \\ 1,3 Taprobanica Nature Conservation Society, 146, Kendalanda, Homagama, Sri Lanka \\ ${ }^{2}$ IUCN - Sri Lanka Country office, No. 53, Horton place, Colombo 07, Sri Lanka \\ Email: ${ }^{1}$ aathasun @ gmail.com; ${ }^{2}$ dmsameera @gmail.com
}

Date of publication (online): 26 November 2009 Date of publication (print): 26 November 2009 ISSN 0974-7907 (online) | 0974-7893 (print)

Editor: Aaron Bauer

\section{Manuscript details:}

Ms \# 02216

Received 25 May 2009

Final received 28 October 2009

Finally accepted 29 October 2009

Citation: Amarasinghe, A.A.T., D.M.S.S Karunarathna \& D.E. Gabadage (2009). Current status of Calotes liocephalus Günther, 1872 (Reptilia: Agamidae) of Sri Lanka. Journal of Threatened Taxa 1(11): 553-557.

Copyright: $\odot$ A.A. Thasun Amarasinghe, D.M.S Suranjan Karunarathna \& Dinesh E. Gabadage 2009. Creative Commons Attribution 3.0 Unported License. JoTT allows unrestricted use of this article in any medium for non-profit purposes, reproduction and distribution by providing adequate credit to the authors and the source of publication.

Author Details: A.A. Thasun Amarasinghe, the chairman of the Taprobanica Nature Conservation Society is a Sri Lankan herpetologist. He is the editor-in-chief of the Taprobanica journal, is an editorial board member of Herpetotropicos, and a member of CSG/SSC/IUCN; currently involved in biodiversity conservation projects in Sri Lanka. D.M.S. SURANJAN KarunarathNa, an instructor of the reptile study group in Young Zoologists Association of Sri Lanka and currently works as a project assistant for the IUCN, Sri Lanka. Also, he is a member of CSG/SSC/IUCN.

Dinesh E. Gabadage, the secretary of the Taprobanica Nature Conservation Society is a field biologist working on Sri Lankan herpetofauna and promoting conservation awareness of the value of biodiversity among Sri Lankans.

Author Contributions: All authors have equally contributed to this study and in writing the paper.

Acknowledgments: We sincerely thank Mohomed M. Bahir for comments; Colin McCarthy for measurements and photographs of Calotes liocephalus holotype; Rohan Pethiyagoda, Sudath Nanayakkara (WHT) for assistance and Kasun Benaragama \& Kasun Ekanayake for photographs.
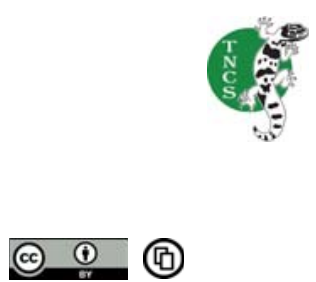

OPEN ACGESS | FREE DOWNLOAD
Abstract: Calotes liocephalus Günther, 1872 is an endemic and threatened, arboreal agamid lizard of Sri Lanka, which is found only in the forests of the Knuckles Mountain Range and Peak Wilderness up to $1850 \mathrm{~m}$. This work is mainly based on examination of the type specimen and WHT specimens as well as published literature and our observations of ecology, behaviour and threats on Calotes liocephalus.

Keywords: Behaviour, biology, Calotes liocephalus, conservation, ecology, natural history, taxonomy, Sri Lanka.

\section{INTRODUCTION}

Eighteen species of agamid lizards, family Agamidae, have been reported from Sri Lanka (Manamendra-Arachchi et al. 2006; Somaweera \& Somaweera 2009), representing one subfamily: Draconinae (Macey et al. 2000; Manthey 2008). The genus Calotes extends through southern Asia to most of the East Indian Archipelago (Taylor 1953).

Seven species of Calotes occur in Sri Lanka. Five of them (C. nigrilabris Peters, 1860; C. liocephalus Günther, 1872; C. liolepis Boulenger, 1885; C. ceylonensis Müller, 1887; C. desilvai Bahir \& Maduwage, 2005) are endemic. The remaining two, C. calotes (Linnaeus, 1758) and C. versicolor (Daudin, 1802) are widespread throughout South and South East Asia. Calotes liocephalus is an arboreal species found only in the forests of the Knuckles Range and Peak Wilderness up to $1850 \mathrm{~m}$ (Erdelen 1984; ManamendraArachchi \& Liyanage 1994; Das \& de Silva 2005; de Silva et al. 2005). It is a threatened species (Manamendra-Arachchi \& Liyanage 1994; Bahir \& Surasinghe 2005; IUCNSL \& MENR 2007).

\section{Materials and Methods}

The examined holotype is at the Natural History Museum, London, UK (BMNH) and others are with the Wildlife Heritage Trust of Sri Lanka, Colombo, Sri Lanka (WHT). Diagnoses and descriptions are based on morphology. The locality record for each species includes WHT specimen data, published information and our observations during the past decade.

All measurements were taken with dial calipers to the nearest $0.1 \mathrm{~mm}$.

Scale counts: SUP - Supralabials were counted from the first scale anterior to that at the angle of gape, not including the median scale (when present); INF - infralabials were counted from the first scale posterior to mental, to the angle of gape; DS - dorsal spines were counted from the first spine to the last of mid-dorsal row; CR - canthus rostralis (counted from rostral scale along scale row passing over nostril to posterior end of supraciliary ridge); MDS - mid dorsal scales (counted from scale behind the rostral to the posterior margin of the thigh); MBS - mid body scales were counted from center of the mid-dorsal row forwards and downwards across ventrals (this count is unreliable, by the unequal size and uneven arrangement of the lateral scales); MVS - mid ventral scales were counted from the first scale posterior to mental, to the last scale anterior to vent; SAT - Spines around tympanum were counted from the first spine to the last above tympanum.

External measurements (in mm): SVL - snout-vent length (distance between tip of snout to anterior margin of vent); HL - head length (distance between posterior edge of mandible and tip of snout); HW - head width (maximum width of head); DHL - dorsal head length (distance between posterior edge of cephalic bone and tip of snout); NFE - nostril - front eye length (distance between anterior most point of orbit and middle of nostril); UAL - upper-arm length (distance between axilla and angle of elbow); LAL - 
lower-arm length (distance from elbow to wrist with both upper arm and palm flexed); FL - finger length (distance between tip of claw and the nearest fork); FEL - femur length (distance between groin and knee); TBL - tibia length (distance between knee and heel, with both tibia and tarsus flexed); TL - toe length (distance between tip of claw and nearest fork); AG axilla-groin length (distance between axilla and groin); SA snout-axilla length (distance between tip of snout and axilla); TAL - tail length (measured from anterior margin of vent to tail tip); PAL - palm length (taken from posterior most margin of palm and tip of longest finger); FOL - foot length (distance between heel and tip of longest toe, with both foot and tibia flexed); TBW - width of tail base (greatest width of the tail base); IOW - inter orbital width (minimum distance between the upper margins of orbits); ED - eye diameter (horizontal diameter of orbit); SFE - snout-front eye length (distance between anterior most point of orbit and tip of snout); SBE snout-back eye length (distance between posterior most point of orbit and tip of snout); SFT - snout-front tympanum length (distance between anterior most point of tympanum and tip of snout); TD - Tympanum diameter (minimum distance between the inner margins of tympanum).

\section{Calotes liocephalus Günther, 1872}

Günther (1872), Annals and Magazine of Natural History.

Boulenger (1885). Catalogue of the Lizards in the British Museum (Nat. Hist.) Burma

Boulenger (1890), The Fauna of British India, including Ceylon and

Smith (1935), The fauna of British India including Ceylon and Burma Deraniyagala (1953), A Colored Atlas of some vertebrates from Ceylon

Taylor (1953), A review of the lizards of Ceylon.

Wermuth (1967). Liste der rezenten Amphibien und Reptilien. Agamidae.

Erdelen (1984). The genus Calotes (Sauria: Agamidae) in Sri Lanka: distribution patterns.

Manamendra-Arachchi \& Liyanage (1994), Conservation and distributions of the agamid lizards of Sri Lanka with illustrations of the extant species.

Manthey \& Schuster (1999). Agamen - 2. Aufl. Natur und Tier Verlag (Münster)

Das \& de Silva (2005), Snakes and other Reptiles of Sri Lanka.

Manthey (2008), Terralog - Agamid Lizards of Southern Asia, Draconinae - 1 .

Amarasinghe et al. (2009), The original descriptions and figures of Sri Lankan Agamid Lizards (Squamata: Agamidae) of the $18^{\text {th }}$ and $19^{\text {th }}$ centuries

Somaweera \& Somaweera (2009). Lizards of Sri Lanka.

English Name: Crestless Lizard; Sinhala Name: Nosilu Katussa

Holotype: Male (90.0mm SVL); Cat.no. BMNH 1946.8.11.33; Loc. Peradeniya District, Ceylon (= Sri Lanka); Coll. G. H.K. Thwaites; Date. Unknown (Images 1 \& 2).

Other material examined: WHT 1667, male, $87.4 \mathrm{~mm}$, Sri Pada; WHT 6241, male, 85.4mm, Corbetts Gap; WHT 6211 , male, $90.8 \mathrm{~mm}$, Knuckles; WHT 6154, male, $89.4 \mathrm{~mm}$, midlands Est.-Knuckles; WHT 0106A, female, $83.6 \mathrm{~mm}$, MaussakandaGammaduwa; WHT 6504, male, $89.1 \mathrm{~mm}$, Agra-Bopath; WHT 6503, female, $82.5 \mathrm{~mm}$, Torrington Est.-Agra-Bopath.

Diagnosis: Head without spines or rarely a rudimentary spine above the tympanum; dorsinuchal crest poorly developed; lateral scales directed backwards and downwards.

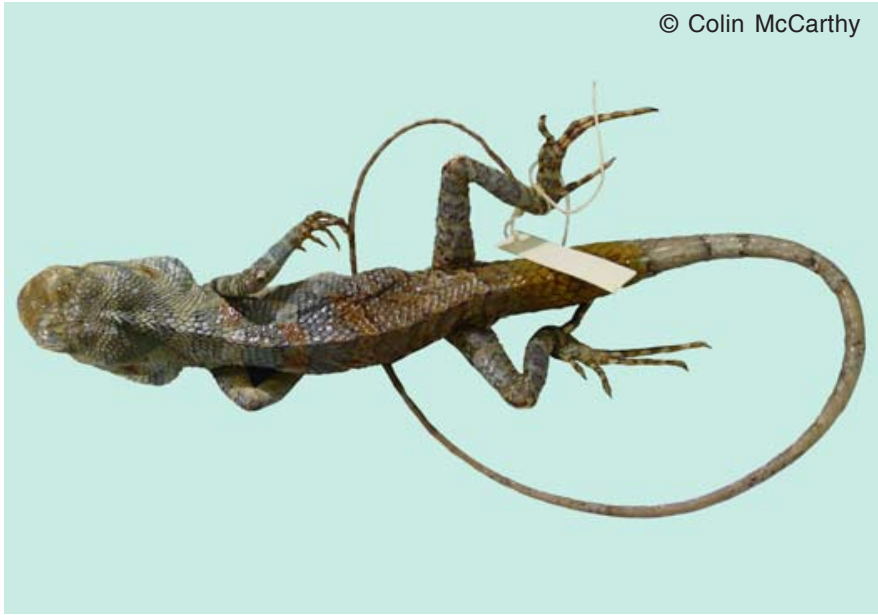

Image 1. C. liocephalus, BMNH 1946.8.11.33; holotype, male, $90.0 \mathrm{~mm} \mathrm{SVL}$; dorsal aspect of the body.

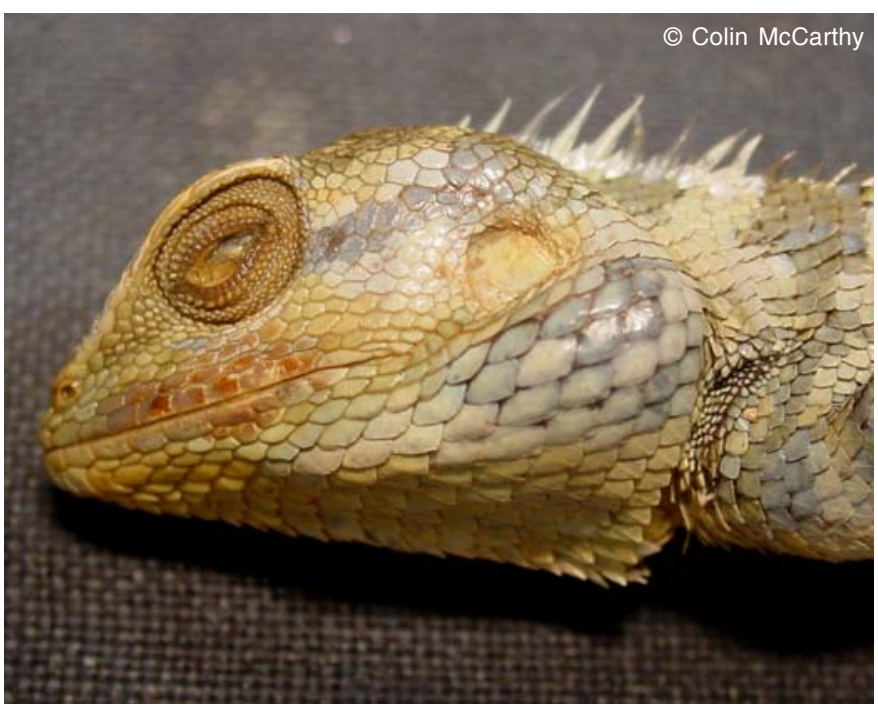

Image 2. C. liocephalus, BMNH 1946.8.11.33; holotype, male, $90.0 \mathrm{~mm}$ SVL; lateral aspect of the head.

Description: [Based on Holotype and WHT collection: (Images 1-2; Figs. 1-3) the range of morphometric data for holotype and WHT specimen shown at the end of the description]. Head without spines or rarely a rudimentary spine above ear, an oblique fold in front of shoulder, lower jaw rather short. Canthus rostralis not very prominent, its outline straight. Six scales from eye to nostril. Tympanum about half size of the orbit. Supraocular scales enlarged. Dorsinuchal crest poorly developed and the spines strongest on head, low on neck and rudimentary on body, scales on sides point backwards and downwards; dorsal scales smaller, feebly keeled, about as large as the ventrals; gular sac undeveloped; gular scales as large as or larger than the ventrals; faintly carinate. Body compressed; Body scales faintly carinate; Ventrals strongly carinate. Limbs moderate; third and fourth fingers equal or fourth finger a little longer than the third. Relative length of fingers; $1<5<2<3<4$. Fourth toe distinctly longer than the third. Relative length of toes; $1<2<5<3<4$. Hind limb reaches to the eye or nearly as far. In a fully-grown male the head is larger and tail is markedly swollen at the base, with 

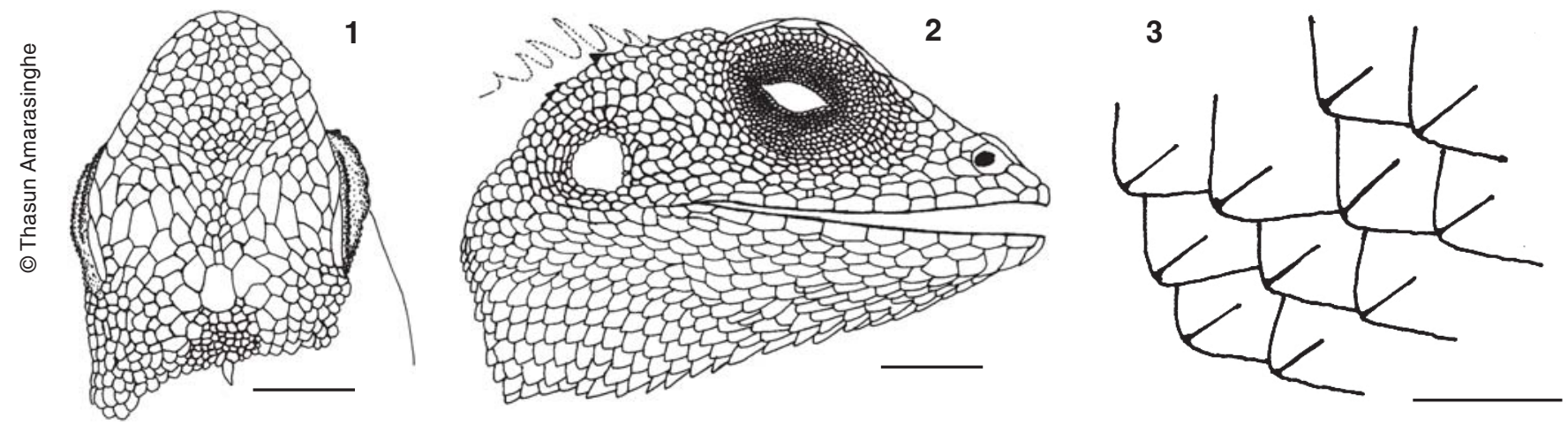

Figures 1-3. C. liocephalus, WHT 6504; male, $89.1 \mathrm{~mm}$ SVL. $($ scale $=1 \mathrm{~cm}$ )

1 - dorsal scalation of head; 2 - lateral scalation of head; 3 - mid body lateral scales.

large, thick, keeled scales. SVL: 82.5-90.0; HL: 27.2-32.4; HW: 17.1-22.0; DHL: 21.4-26.8; NFE: 7.0-8.2; UAL: 16.0-23.5; LAL: $15.5-17.3$; FL I: 5.2-6.4; FL II: 7.4-9.6; FL III: 11.4-13.1; FL IV: 11.5-13.4; FL V: 6.8-7.7; FEL: 20.6-27.3; TBL: 19.624.2; TL I: 5.4-6.8; TL II: 8.1-10.2; TL III: 13.8-16.6; TL IV: 15.5-19.7; TL V: 11.3-14.0; AG: 40.7-51.0; SA: 34.1-45.0; TAL: 241-267; PAL: 15.6-18.1; FOL: 27.9-30.9; TBW: 6.5-11.2; IOW: 1.3-2.3; ED: 5.2-8.1; SFE: 11.4-14.2; SBE: 16.7-19.1; SFT: 22.425.8; TD: 4.0-4.4; SUP: 9-10; INF: 9-9; MDS: 70-78; CR: 8-13; MBS: 45-56; MVS: 68-78; DS: 13-25; SAT: 0-1.

Remarks: [Based on WHT collection and other observations on live specimens: (Images $3 \& 4$ )]. The body colour is green or bluish-green dorsally with five or six transverse dark cross bars. The throat is yellowish-green. Three black cross bands from eye to eye. A black band runs along posterior half or upper lip through the tympanum. Sides of the lower jaws are with black spots, sometimes dark cross bars on the top of the head; base of the tail light olive brown, the rest of it alternately banded with light and dark; below greenish-white.

Distribution and habitat: Calotes liocephalus appears to be rare and has been recorded only from the forests of the Knuckles Range (from 800-1850 m) and Peak Wilderness (from 800$2000 \mathrm{~m}$ ) and this species is endemic to Sri Lanka. This species is largely arboreal and its diet comprises of young leaves, buds, insects and worms (de Silva et al. 2005).

Hemipenis morphology: The hemipenis of Calotes liocephalus (Image 5) is well developed. The pedicel is slightly shorter than the head; below the head, it is broadened out in to two shallowly concave shoulders; there are no spines. The head is quadrangular, shallowly divided longitudinally into four lobes, two being slightly larger. Surface of the head is reticulatedly pitted, the pits being larger on the outside, diminishing in size towards the divisions between the lobes.

Nest hole and eggs: A female dug a hole in the ground $92.6 \mathrm{~mm}$ deep and $79.1 \mathrm{~mm}$ in diameter. $3-8$ eggs were deposited in June. The bottom of the hole is conical and is dug at $45^{\circ}$ angle. The eggs were white and elliptic, with a mean length of $14.8 \mathrm{~mm}$ and $8.6 \mathrm{~mm}$ width $(\mathrm{n}=8)$. While laying eggs $C$. liocephalus places the posterior part of its body inside the hole (Fig. 4) and it does not lift the posterior part of the body to lay eggs. Its entire body curls inside the hole, bending the anterior part of its body to look around (see Amarasinghe \& Karunarathna 2008).

Other behaviour: This species is active during daytime, largely arboreal and sometimes on trees $5 \mathrm{~m}$ above ground level.

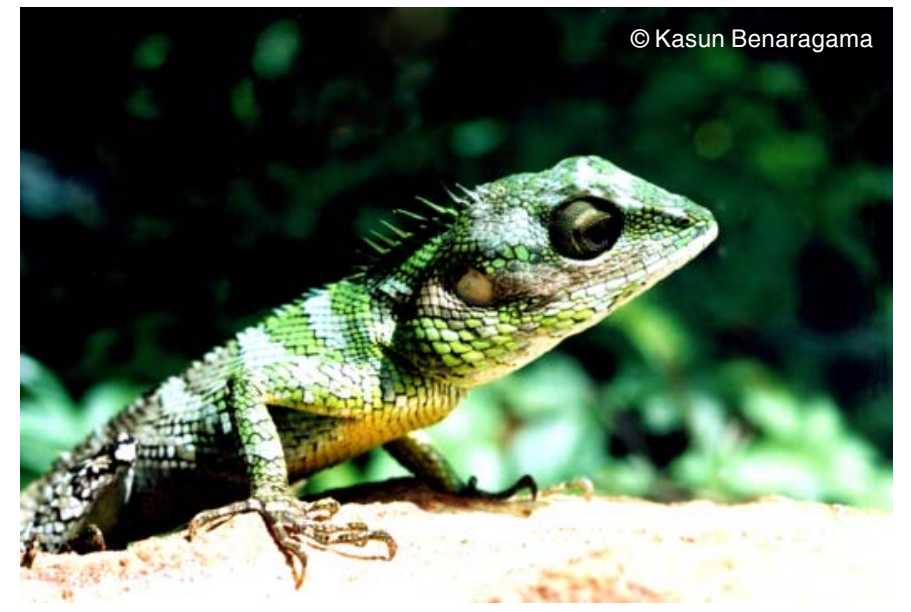

Image 3. C. liocephalus mature male.

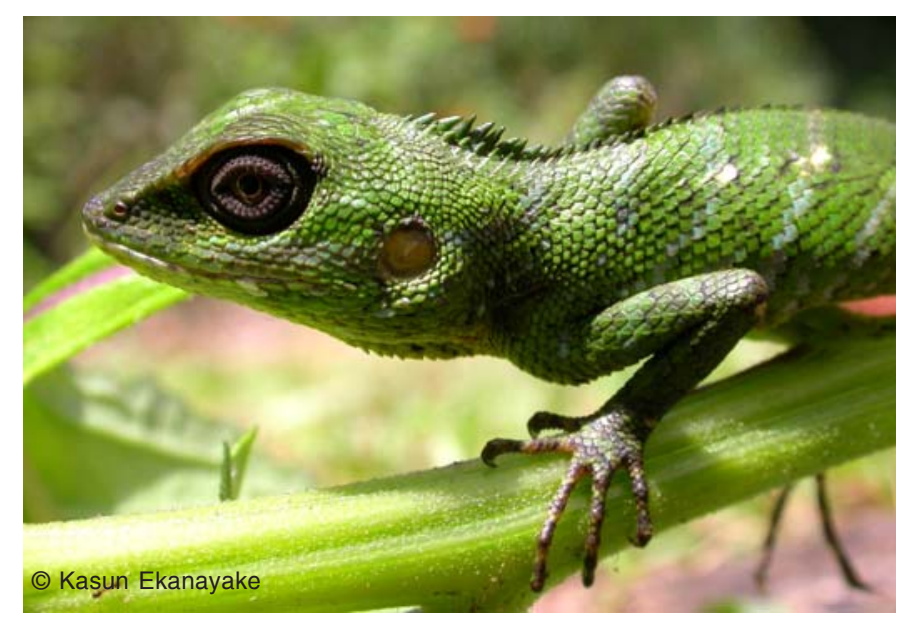

Image 4. C. liocephalus mature female.

C. liocephalus is widespread within moderately open riverineforested areas and uncommon in home gardens. Hatchlings typically ambush their prey on Strobilanthes bushes, camouflaging in light green. On threat, these hatchlings creep in to the bush. Adults usually perch vertically on branches. In the Knuckles Range we located this species on Mallotus tetracoccus (Euphorbiaceae) trees. When threatened the lizard rapidly climbs on a tree or shrub and flattens against a branch. They 


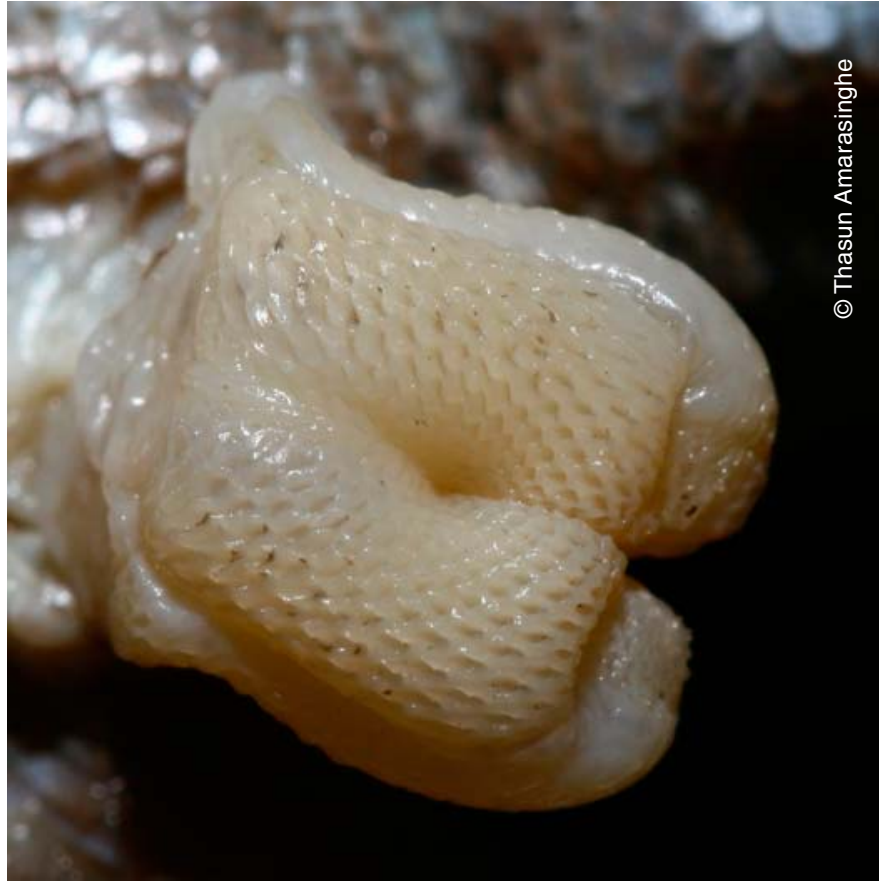

Image 5. C. liocephalus, WHT 6154; male, 89.4 mm SVL; left hemipenis.

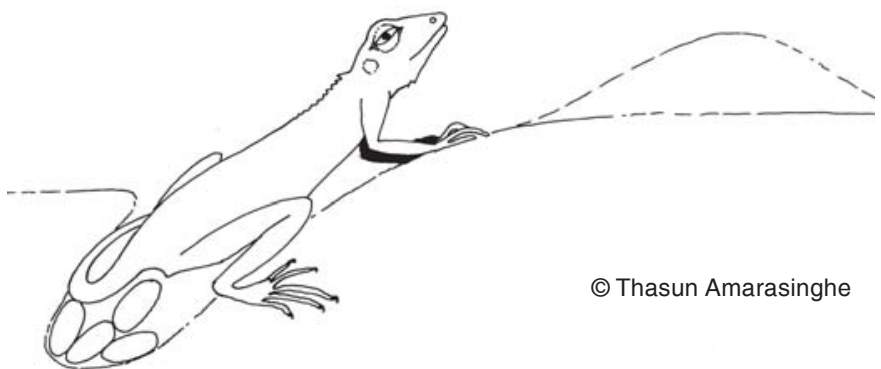

Figure 4. Egg laying of C. liocephalus.

also change their body colour to black.

Threats: Forest clearing and habitat fragmentation are major threats to Calotes liocephalus (de Silva et al. 2005), exacerbated by montane forest fragments surrounded by cardamom plantations involving intensive pesticide application. We observed many dead sub-adults of C. liocephalus individuals, after very cold nights in December and January on the branches of trees in the Knuckles Range, reasons for mortality unknown.

\section{Discussion}

According to Manamendra-Arachchi et al. (2006) the lowlands (elevation $\sim 500 \mathrm{~m}$ ) of the Mahaweli River, which separates the Dumbara Hills (= Knuckles Hills) from the Central Mountains, appears to have served as a barrier to the dispersion of highland species. According to Günther (1872) the holotype of Calotes liocephalus (BMNH 1946.8.11.33), was collected from "Peradeniya District" presumably, Peradeniya (alt. $\sim 500 \mathrm{~m})$ in the Kandy District. However, Peradeniya is on the margin of the Knuckles and Central Hills and the Mahaweli River flows across Peradeniya. If the report is correct, $C$. liocephalus was once distributed throughout the low elevations

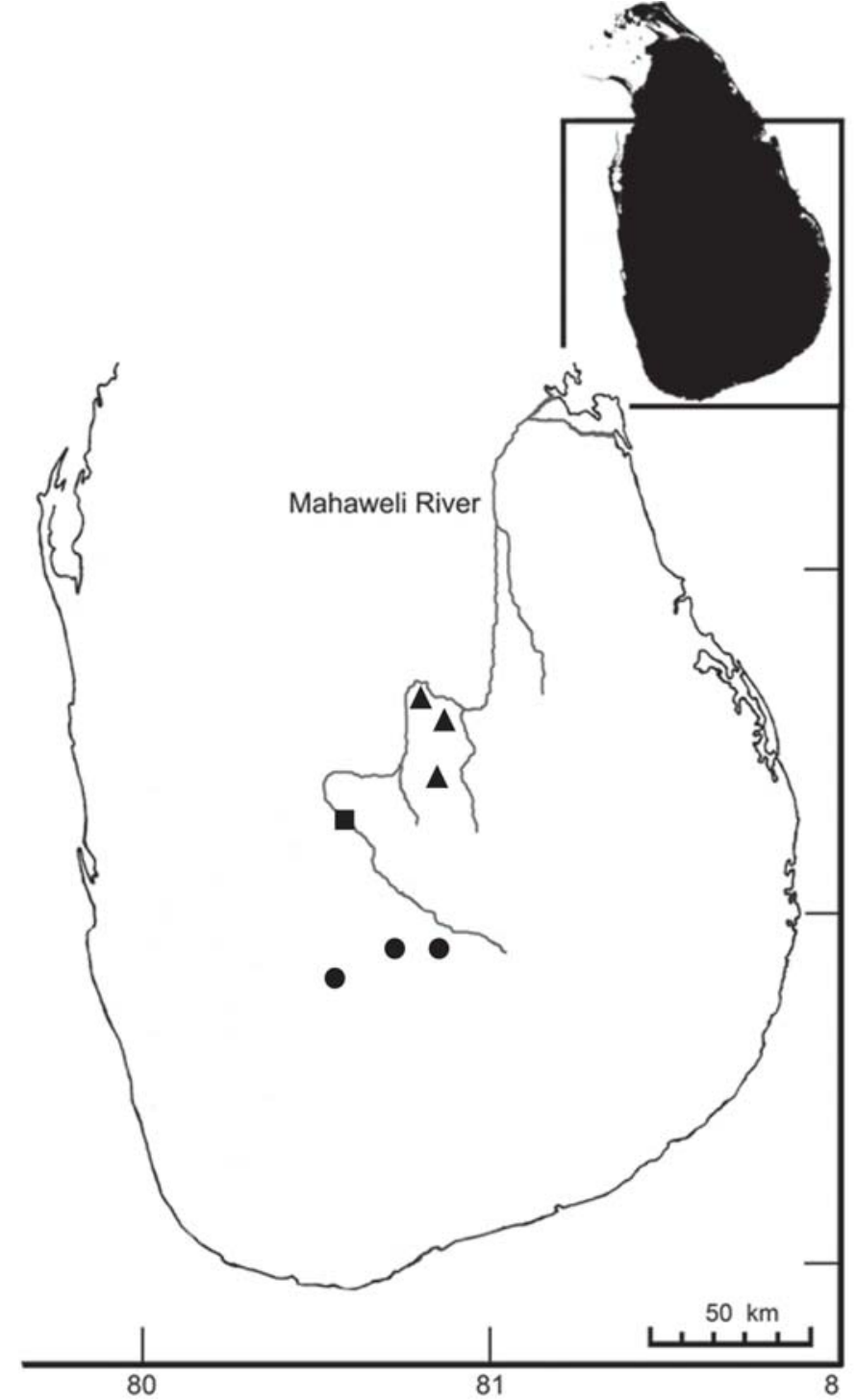

Figure 5. Distribution of C. liocephalus populations - Central-hill population; $\boldsymbol{\Delta}$ - Knuckles population, - Type locality

of Central and Knuckles Mountains. We could not locate any Calotes liocephalus specimen in Peradeniya. Two isolated populations in the Central Hills and Knuckles Region occur and these have not been compared critically (Fig. 5). Therefore, a morphological and morphometric analysis of the two isolated C. liocephalus populations is needed. If the Knuckles population is a distinct morphospecies, its range would be restricted to the Knuckles massif and it would be at risk of extinction before it is even named.

\section{References}

Amarasinghe, A.A.T. \& D.M.S.S. Karunarathna (2008). Observations on the ovipositional behavior of the Crest - Less Lizard Calotes liocephalus (Reptilia: Agamidae) in the Knuckles Forest Region of Sri Lanka. Asiatic Herpetological Research 11: 13-16.

Amarasinghe, A.A.T., U. Manthey, E. Stöckli, I. Ineich, S. O Kullander, F. Tiedemann, C. McCarthy \& D.E. Gabadage (2009). The original descriptions and figures of Sri Lankan Agamid Lizards (Squamata: Agamidae) of the $18^{\text {th }}$ and $19^{\text {th }}$ centuries. Taprobanica 1 (1): 2-15+4 
pls.

Bahir, M.M. \& T.D. Surasinghe (2005). A conservation assessment of the agamid lizards of Sri Lanka, pp. 407-412. In: Yeo, D.C.J., P.K.L. $\mathrm{Ng} \&$ R. Pethiyagoda (eds.). Contributions to Biodiversity Exploration and Research in Sri Lanka. The Raffles bulletin of Zoology Supplement 12 .

Boulenger, G.A. (1885). Catalogue of the Lizards in the British Museum (Nat. Hist.) - I. Geckonidae, Eublepharidae, Uroplatidae, Pygopodidae, Agamidae. London, 450pp.

Boulenger, G.A. (1890). The Fauna of British India, including Ceylon and Burma: Reptilia and Batrachia. Taylor and Francis, London, xviii+541pp.

Das, I. \& A. de Silva (2005). Snakes and other Reptiles of Sri Lanka. New Holland Publishers, UK. 144pp.

Deraniyagala (1953). A Colored Atlas of Some Vertebrates from Ceylon, Tetrapod Reptilia Vol - 2. National Museums of Sri Lanka, 101pp.

de Silva, A., A.M. Bauer, S. Goonewardene, J. Drake, S. Nathanael, W.P.R. Chandraratne, S.A.U.S. Somathilaka (2005). Status of the agamids in the Knuckles massif with special reference to Calotes liocephalus Günther, 1872 and Cophotis ceylanica Peters, 1861. Lyriocephalus 6(1\&2): 43-71.

Erdelen, W. (1984). The genus Calotes (Sauria: Agamidae) in Sri Lanka: distribution patterns. Journal of Biogeography 11: 515-525

Günther, A. (1872). Descriptions of some Ceylonese Reptiles and Batrachians. Annals and Magazin of Natural History (4)9: 85-88.

IUCNSL \& MENR (2007). The 2007 Red List of threatened Fauna and Flora of Sri Lanka. Colombo, IUCN Sri Lanka, 148pp.
Macey, J.R., J.A. Schulte \& A. Larson (2000). Evolution and phylogenetic information content of mitochondrial genomic structural features illustrated with acrodont lizards. Systematic Biology 49(2): 257-277.

Manamendra-Arachchi, K., A. de Silva \& T. Amarasinghe (2006). Description of a second species of Cophotis (Reptilia:Agamidae) from the highlands of Sri Lanka. Lyriocephalus 06: Supplement 1: 1-8.

Manamendra-Arachchi, K. \& S. Liyanage (1994). Conservation and distributions of the agamid lizards of Sri Lanka with illustrations of the extant species. Journal of South Asian Natural History 1(1): 77-96.

Manthey, U. \& N. Schuster (1999). Agamen - 2. Aufl. Natur und Tier Verlag (Münster), 120pp.

Manthey, U. (2008). Terralog - Agamid Lizards of Southern Asia, Draconinae - 1. Edition Chimaira, 160pp.

Smith, M.A. (1935). The Fauna of British India including Ceylon and Burma, Reptilia and Amphibia, Volume II - Sauria, 144-206pp.

Somaweera R. \& N. Somaweera (2009). Lizards of Sri Lanka: A Colour Guide with Field Keys. Edition Chimaira, Germany, 303pp.

Taylor, E.H. (1953). A review of the lizards of Ceylon. The University of Kansas Science Bulletin 35 (12): 1525-1585.

Wermuth, H. (1967). Liste der rezenten Amphibien und Reptilien. Agamidae. Das Tierreich - 86. Walter de Gruyter, Berlin, xiv+127pp. 